\title{
Asset Quality, Non-Interest Income, and Bank Profitability: Evidence from Indonesia
}

\author{
Febrio Giring Tolangga, Maria Ulpah
}

\author{
Faculty of Economics and Business, Universitas Indonesia, Depok, Indonesia \\ *Corresponding author. Email: maria.ulpah@ui.ac.id
}

\begin{abstract}
This paper aims to investigate whether increases in non-interest income activities result in higher profitability of banks operating in Indonesia and how they differ from groups of banks based on ownership status and asset quality. Our findings show that the relationship between income diversification and bank profitability is statistically insignificant, although the relationship between the two measurements is positive. Furthermore, from income diversification, lower asset quality banks enjoy higher benefits than higher asset quality banks. The findings are found to be sensitive to dynamic estimators and possible alternative sample specifications.
\end{abstract}

Keywords: Income Diversification, Bank, Bank Profitability, Non-Interest Income, Asset Quality

\section{INTRODUCTION}

Since the beginning of 1980, the financial sector in many countries in Asia, such as India and Indonesia, has undergone deregulation and liberalization as financial reforms. Market-based interest rates, privatization of financial institutions, elimination of directed credit programs, and control over foreign exchange trading are the drivers of the reforms. However, if the reforms in Asia are led by those changes, then they are based on a misunderstanding over what is needed to build a market-based financial system.

Indonesia made significant changes in the banking sector through financial reforms. These changes started with the release of Paket Juni 1983 (Pakjun 83) regarding a non-ceiling policy in interest rates. The government is determined to create a free and more competitive environment in the banking sector to drive banks to expand their businesses. After the successful execution of Pakjun 83, the government further liberalized the banking sector by releasing Paket Oktober 1988 (Pakto 88), which marked the beginning of the liberalization of the Indonesian banking sector. The main purposes of Pakto 88 are to increase the mobilization and allocation of funds in the banking sector, improve the use of financial and banking institutions in exporting activities, improve efficiency in forming a new banking institution, improve control over monetary policies, and develop the Indonesian capital market.

All deregulation policies by the Indonesian government created a healthier, more efficient, and strong banking system and supporting each bank to adopt a competitive attitude. This competitiveness can be observed from banks' finding new sources of income to avoid being too reliant on traditional activities. Pakto 88 is believed to have modernized the Indonesian banking sector and pushed its economic growth. PostPakto 88 release, Indonesia's economic growth has always been higher than $6.5 \%$ until the end of 1998 when the financial crisis emerged in the country.

The number of banks operating in Indonesia has continued to grow significantly since the implementation of the deregulation policies that led to stricter competition in the industry. Therefore, income diversification has become an important role in a bank's business activities. Bank income in Indonesia and the Asia region has begun to shift toward non-traditional activities that generate non-interest income, such as fees, commissions, and securities trading, from traditional activities that generate interest income. However, the extent of the diversification is limited to a bank's size, capability, resources, and technology capacity. Thus, the effect of income diversification on 
bank profitability differs for each bank, especially for banks with different ownership statuses.

The effect of income diversification on bank profitability is also affected by the quality of bank assets. This aspect can be measured by the level of a bank's loan loss provisions (LLP) and non-performing loans (NPL). In Indonesia, the average NPL has been steadily rising for the past three years, a result of the economic slowdown and a decrease in global commodity prices in general. This phenomenon has resulted in more banks having low-asset quality over the past few years, which has led to lower bank profitability and has induced higher income diversification in the future. Moreover, Otoritas Jasa Keuangan (OJK) forecasted that future net interest margins would decline as regulators support the efforts of domestic and foreign banks operating in Indonesia to apply single-digit lending interest rates. Consequently, non-traditional activities are expected to have an upward trend to compensate for the possible losses of lending activities and remain profitable and competitive in the industry.

Several previous empirical studies for banks in developing countries, such as Ahamed (2017) in India, Meslier et al. (2014) in the Philippines, and Sanya and Wolfe (2011) in 11 developing countries, found that increasing income diversification by generating more non-interest income is resulting in higher profit and risk-adjusted profit than relying solely on interest income. These findings are not in line with previous studies by Stiroh (2002) and Stiroh and Rumble (2006) on banks and holding companies in the financial industry (FHC) in the United States. They found that income diversification has an insignificant impact on bank profitability. They also found that higher specialization in generating interest income is associated with higher profitability.

Restructuring a bank's source of income can be accomplished only when the bank has adequate asset size, capability, resources, and technology capacity. Consequently, the impact of income diversification on bank profitability will differ for each group of banks based on ownership status. Previous empirical studies by Ahamed (2017) and Pennathur et al. (2012) found that foreign banks in India generally gain higher riskadjusted profits than banks with another ownership status - public and private banks. The findings of these studies are based on foreign banks' better ability to apply technology and managerial skills. This finding supports those of Meslier et al. (2014) regarding foreign banks in the Philippines that receive higher risk-adjusted profits than public banks.

The effect of income diversification is also affected by the quality of the assets owned by a bank. This aspect could be measured using banks' level of LLP and NPL. The increasing tendency of the NPL ratio in
Indonesia will surely positively affect the rate of income diversification of each bank.

\section{LITERATURE REVIEW}

\subsection{Income Diversification and Bank Profitability}

In accordance with Sanya and Wolfe (2011) and Meslier et al. (2014), income diversification can be explained as a bank's effort to reduce its reliance on the interest income obtained from loan interest from debtors. A bank can diversify by broadening its source of income from bank services, such as by engaging in underwriting and securities trading, brokerage and investment banking, and other activities that generate non-interest income.

The benefit of income diversification on bank profitability still cannot be explained clearly, considering that an intense debate has continued over the issue for the past decade. Elsas et al. (2010) stated in their research report that banks with a diversified income portfolio can acquire greater benefits through non-traditional activities. Those benefits are gained through better implementation of economies of scale, better resource allocation through internal funding schemes, and distinctive quality from the rest in the industry. Goddard et al. (2008) also found that banks with significant income diversification are able to reduce their exposure to idiosyncratic risks and strengthen their financial systems.

The findings of previous empirical studies are ambiguous and mostly based on developed economies, such as Europe or the United States. Previous empirical studies, including Baele et al. (2007), who investigated 17 countries in Europe; Chiorazzo et al. (2008), who investigated the banking industry in Italy; and Elsas et al. (2010), who investigated nine developed countries' markets, found that income diversification positively affects bank profitability. However, the theory against these findings suggests that greater income diversification might have a negative impact on bank profitability. The implicit cost associated with diversifying income sources might outweigh the obtained benefits. Elsas et al. (2010) could not ignore this issue and addressed the matter by listing the identified costs, including agency problems regarding investment diversification, problems that arise from an inefficient allocation of available resources given errors in the internal funding scheme, and problems with asymmetric information caused by miscommunication between the central office and managers in local offices. Goddard et al. (2008) also stated that the agency problem would probably arise when managers intend to seek higher growth through income diversification by investing excessively in risky investments than doing what shareholders require. In addition, Stiroh and 
Rumble (2006) believed that earnings from diversification are more prone to volatility than traditional activities that lead to less profitable income.

A limited number of available studies on markets in developing countries is present because previous studies focused on developed markets. Meslier et al. (2014) began a study on emerging markets by taking samples from Philippines banks for the period 1999-2005 and found that a shift toward non-traditional activities enhances bank profitability and that foreign banks benefit more from diversification than domestic banks. Nguyen et al. (2012) also studied the emerging markets by obtaining data from banks in a few South Asian countries, including India, Bangladesh, Sri Lanka, and Pakistan, for 1998-2008. They found that South Asian banks with higher-levels of market power tend to be more stable with a diversified income portfolio.

Indonesia is one of the most important, fast-growing emerging market economies throughout the world. However, understanding the possible impact of income diversification on bank profitability is still not the main focus. Unlike most existing studies, this research applies Herfindahl-type income diversification to test whether banks generate higher profitability by shifting toward non-traditional bank activities. Finally, this paper intends to enrich the context of previously existing studies in Indonesia and investigate the first hypothesis by applying the sample data using static and dynamic panel data estimators to present empirical evidence on banks in Indonesia.

Hypothesis 1. A shift toward non-interest income activities increases the profitability and risk-adjusted profitability of commercial banks operating in Indonesia.

\subsection{Ownership Status, Income Diversification, and Bank Profitability}

Each group of banks based on ownership status has distinctive objectives and organizational structures, resulting in dissimilar effects on bank profitability. The existing studies that investigate the impact of ownership status on bank profitability also had different results. Several studies suggested that foreign banks are more profitable (e.g., Berger et al., 2009, others suggested that public or state-owned banks are more efficient at profit-generating activities (Das and Ghosh, 2006, 2009; Tabak and Tecles, 2010). Micco et al. (2007) found no evidence that private banks have higher profitability than government banks in developed countries but found statistically significant evidence in developing countries. However, Degl'Innocenti et al. (in press) found that the operational efficiency of government banks can be enhanced, such as the privatization of Central and Eastern European countries during 19942009 showed. Based on the previous statement,
Indonesia's state-owned banks will probably improve their profit efficiency through the implementation of Pakjun 83 and Pakto 88. Thus, this paper aims to investigate whether increasing non-traditional banking activities has different effects on bank profitability for different ownership groups.

Hypothesis 2. A shift toward non-interest income has different effects on the profitability and riskadjusted profitability of commercial banks in Indonesia across different ownership groups.

\subsection{Asset Quality, Non-Interest Income, and Bank Profitability}

A bank's financial soundness has direct or indirect effects on its profitability. Soundness can be measured using various types of measurement, one of which is the bank's asset quality. Therefore, to consider asset quality is important because it represents financial soundness and bank health. Although a negative effect of lower asset quality on profitability has been statistically proven, the relationship between the two measurements of banks with different asset quality is still limited. Banks with different asset quality may have different motivations for non-interest income activities.

Beck et al. (2013) and Mirza et al. (2015) applied the ratio of LLP over total assets to determine a bank's asset quality. The research further explains that when the debtor fails to comply with payment contracts, the creditor's asset quality will decline and negatively impact the bank's interest income. Consequently, the decline in interest income might result in lower bank profitability if the bank's majority activities include traditional lending. Another means of measurement is available: Banerjee and Velamuri (2015) applied the ratio of NPL over total assets to determine the bank's asset quality. Thus, we test the third hypothesis to understand whether any difference exists in the impact of income diversification on bank profitability considering asset quality.

Hypothesis 3. A shift toward non-interest income results in higher benefits for lower asset quality banks than the higher ones.

\section{DATA AND METHODOLOGY}

The researcher collected a homogenous sample from commercial banks in Indonesia for the period 20072016. The main source of data on the balance sheets, income statements, and annual reports of the banks was from Statistik Perbankan Indonesia, provided by OJK. Observations with missing data for any of the variables are eliminated from the sample data; therefore, we are using an unbalanced panel dataset. The sample includes 109 commercial banks operating in Indonesia during the 
research period, of which 31 are public or state-owned, 52 are privately owned, and 26 are foreign.

\subsection{Income Diversification Measures}

Following previous studies by Stiroh and Rumble (2006), Meslier et al. (2014), and Ahamed (2017), we measure income diversification using a Herfindahl-type diversification indicator (FOCUS) as follows:

$$
F O C U S_{i t}=\left(\frac{N I N}{N T O P}\right)^{2}+\left(\frac{I N T}{N T O P}\right)^{2}
$$

where two types of income-non-interest income and interest income-construct the total value of net operating income (NTOP). FOCUS is a measure for determining the degree of diversification in a bank's net total operating profit (NTOP), for which higher values reflect less diversified or more focused banks and vice versa. Non-interest income does not necessarily have to be high to lower the value of FOCUS. Banks with a balanced proportion of sources of revenue will have a lower value. Therefore, FOCUS is suitable for use in this research.

We also include the calculation of the share percentage of non-interest income in the total operating income portfolio (NII) to account for each bank's income diversification. Because banks in Indonesia are likely to have interest income as their main source of revenue, this ratio needs to be included in the research.

\subsection{Profitability and Risk-Adjusted Profitability Measures}

In this study, to measure for bank profitability, we apply two ratios as means of measurement, which are (1) return on assets, obtained by dividing net income by total assets (ROA) and (2) risk-adjusted return on assets, obtained by dividing ROA by the standard deviation of ROA (ROA/SDROA). To calculate the standard deviation of ROA, we calculate the volatility of ROA over the past three years for each respective year to count for the risk of each bank's assets.

Banks' profitability is better reflected using ROA than ROE because ROA accounts for the efficiency of banks in utilizing their assets, which are comprised of loans, which reflect interest-bearing activity.

\subsection{Controls for Bank Characteristics}

The logarithm of total assets is applied to test whether bank size significantly affects its profitability. The main advantages of larger banks are more significant opportunities to engage in income diversification by reaching out to new, penetrable markets and reducing the volatility in income (Stiroh and Rumble, 2006; Baele et al., 2007; Sanya and Wolfe, 2011). In contrast, smaller banks have fewer opportunities to diversify their income because they are unable to penetrate new markets and maintain a stable income.

To control for the credit risk underlying each bank's loans, we apply the ratio of loan loss provisions to total assets (LLP ratio). The LLP ratio reflects the quality of the loans of each bank; in other words, the LLP ratio can be used to determine a bank's asset quality (Mergaerts and Vander Vennet, 2016). A bank that makes more provisions has a higher bank asset risk, and it can be classified as having lower quality assets. Banks are able to use provisions to smoothen their earnings in the future; therefore, including the ratio in the research model is important (Laeven and Majnoni, 2003). Based on Chiorazzo et al. (2008) and Meslier et al. (2014), to determine bank capital, we apply the ratio of equity capital to total assets. Differences in the bank capital amount will affect the impact of income diversification on profitability because higher bank capital is associated with a better ability to diversify sources of income than lower bank capital.

Each bank's asset composition can be controlled using the percentage of total loans of the bank's total assets (LoanRatio), following several previous studies (e.g., Stiroh and Rumble, 2006; Chiorazzo et al., 2008; Chortareas et al., 2011; Garza-Garcia, 2012; Meslier et al., 2014). Banks with a higher loan ratio are associated with more aggressive operational activities, given a larger portion of interest-bearing assets. Finally, the annual growth in total assets (AssetGrowth) is measured to control the stage of the business cycle that each bank is in. Banks in their mature stage are likely less aggressive in generating revenue.

Table 1, Panel A shows the statistics for all entities included in the sample data. The average ROA is $1.28 \%$ and has a maximum value of $9.92 \%$ and minimum value of $-130.35 \%$. The overall average of the risk-adjusted profits is 7.84 . The average NII is $12.09 \%$, with highest the value being $99.51 \%$ and the lowest value being $-0.15 \%$.

Panel B presents the statistics of each group of banks based on ownership status. These data show that, in general, public banks have higher profitability than private and foreign banks, with $2.26 \%$ of ROA compared with $0.6 \%$ and $1.48 \%$ for private and foreign banks, respectively. This result is because of public banks' dominance in Indonesia and the good sentiments that people have toward them. Meanwhile, foreign banks are more diversified, proven by the lowest value of FOCUS at 0.682 , and the highest value of NII at $29.44 \%$, relative to the other two groups. Therefore, foreign banks are less risky in maintaining their operations because they have several other revenue sources than interest income. They also have a higher loan loss provision ratio $(0.68 \%)$, which can cover up 
any losses in the future, even though the difference is not very significant.

Panel C provides the statistics of banks based on the asset quality group. To differentiate among banks, we use the LLP ratio and establish two groups of banks: low-asset quality (LAQ) and high-asset quality (HAQ). In line with this classification is that HAQ banks have higher profitability than the other group because they have more solid assets to back up their investments. However, in terms of income diversification, the HAQ banks are less diversified than the LAQ banks.

Table I. Summary Statistics

\begin{tabular}{|c|c|c|c|c|c|c|c|c|c|c|}
\hline & & $R O A$ & ROASDROA & FOCUS & NII & LogTA & LLPRatio & EquityRatio & LoanRatio & AssetGrowth \\
\hline Panel A & \multicolumn{10}{|c|}{ Descriptive Statistics for All Banks } \\
\hline All Banks & Mean & 0.0149 & 7.9541 & 0.8322 & 0.1212 & 6.9021 & 0.0058 & 0.1524 & 0.6101 & 0.2120 \\
\hline \multirow[t]{3}{*}{$($ Obs. $=1062)$} & Std. Dev. & 0.0127 & 14.9912 & 0.1298 & 0.1504 & 0.7624 & 0.0090 & 0.1201 & 0.1374 & 0.3209 \\
\hline & Minimum & -0.0469 & -10.9963 & 0.5001 & 0.0003 & 4.9480 & 0.0000 & -0.0091 & 0.0136 & -0.5362 \\
\hline & Maximum & 0.0992 & 205.1432 & 1.0030 & 0.9951 & 8.9841 & 0.1153 & 2.0295 & 0.8971 & 3.5627 \\
\hline Panel B & \multicolumn{10}{|c|}{ Descriptive Statistics by Bank Ownership Type } \\
\hline Public Bank & Mean & 0.0233 & 11.3522 & 0.8826 & 0.0644 & 7.1028 & 0.0062 & 0.1180 & 0.6142 & 0.1588 \\
\hline \multirow{3}{*}{$($ Obs. $=304)$} & Std. Dev. & 0.0099 & 18.4867 & 0.0623 & 0.0398 & 0.6727 & 0.0083 & 0.0315 & 0.1144 & 0.2142 \\
\hline & Minimum & -0.0246 & -1.9517 & 0.6277 & 0.0207 & 5.9032 & 0.0000 & 0.0565 & 0.1784 & -0.2215 \\
\hline & Maximum & 0.0550 & 205.1432 & 0.9595 & 0.2473 & 8.9841 & 0.0525 & 0.2064 & 0.8926 & 2.8738 \\
\hline \multirow{4}{*}{$\begin{array}{l}\text { Private Bank } \\
(\text { Obs. }=506)\end{array}$} & Mean & 0.0097 & 6.9215 & 0.8774 & 0.0685 & 6.6888 & 0.0051 & 0.1761 & 0.6192 & 0.2392 \\
\hline & Std. Dev. & 0.0111 & 14.7098 & 0.0802 & 0.0505 & 0.8541 & 0.0090 & 0.1298 & 0.1244 & 0.3649 \\
\hline & Minimum & -0.0447 & -10.9963 & 0.5902 & 0.0030 & 4.9480 & 0.0000 & 0.0290 & 0.0136 & -0.3232 \\
\hline & Maximum & 0.0868 & 193.8156 & 0.9941 & 0.2876 & 8.8212 & 0.1153 & 0.9515 & 0.8802 & 3.5627 \\
\hline \multirow{4}{*}{$\begin{array}{l}\text { Foreign Bank } \\
(\text { Obs. }=252)\end{array}$} & Mean & 0.0153 & 5.9284 & 0.6806 & 0.2954 & 7.0881 & 0.0066 & 0.1463 & 0.5870 & 0.2215 \\
\hline & Std. Dev. & 0.0132 & 9.0455 & 0.1528 & 0.2206 & 0.5176 & 0.0097 & 0.1525 & 0.1794 & 0.3271 \\
\hline & Minimum & -0.0469 & -1.6563 & 0.5001 & -0.0015 & 5.7556 & 0.0000 & -0.0091 & 0.0336 & -0.5362 \\
\hline & Maximum & 0.0992 & 99.4244 & 1.0030 & 0.9951 & 8.1479 & 0.0705 & 2.0295 & 0.8971 & 1.6410 \\
\hline Panel C & \multicolumn{10}{|c|}{ Descriptive Statistics by Asset Quality Group } \\
\hline \multirow{4}{*}{$\begin{array}{l}\text { Low-Asset Quality Bank } \\
(\text { Obs. = 533) }\end{array}$} & Mean & 0.0106 & 8.7315 & 0.8159 & 0.1286 & 7.1246 & 0.0113 & 0.1412 & 0.6368 & 0.1666 \\
\hline & Std. Dev. & 0.0594 & 17.8532 & 0.1314 & 0.1416 & 0.7788 & 0.0157 & 0.1177 & 0.1081 & 0.2423 \\
\hline & Minimum & -1.3035 & -10.9963 & 0.5001 & -0.0015 & 5.1624 & 0.0001 & -0.2749 & 0.2044 & -0.6082 \\
\hline & Maximum & 0.0550 & 205.1432 & 1.0030 & 0.8489 & 8.9841 & 0.2205 & 2.0295 & 0.8971 & 2.8377 \\
\hline \multirow{4}{*}{$\begin{array}{l}\text { High-Asset Quality Bank } \\
(\text { Obs. }=541)\end{array}$} & Mean & 0.0149 & 6.9653 & 0.8483 & 0.1133 & 6.6674 & 0.0014 & 0.1654 & 0.5828 & 0.2511 \\
\hline & Std. Dev. & 0.0145 & 11.3243 & 0.1254 & 0.1570 & 0.6798 & 0.0025 & 0.1276 & 0.1578 & 0.3794 \\
\hline & Minimum & -0.1032 & -4.6004 & 0.5001 & 0.0000 & 4.9480 & 0.0000 & -0.0091 & 0.0136 & -0.5304 \\
\hline & Maximum & 0.0992 & 133.5625 & 1.0000 & 0.9951 & 8.7340 & 0.0100 & 0.9515 & 0.8570 & 3.5627 \\
\hline
\end{tabular}

The statistics indicate that LAQ banks (12.86\%) have higher NII than HAQ banks $(11.33 \%)$ and a lower FOCUS value, at 0.816 , relative to 0.848 of HAQ banks. Therefore, because LAQ banks do not possess solid assets to back up their investments, they search for alternatives to gain revenue and, hence, have more diversified sources of income.

\subsection{Empirical Model}

To investigate the impact of diversification of sources of income on bank profitability, we implement the following empirical model:

$$
Y_{i t}=\alpha_{0}+\alpha_{1} Y_{i(t-1)}+\beta_{1} \text { FOCUS }_{i t}+\beta_{2} N I I_{i t}
$$

where $Y_{\text {it }}$ is ROA or risk-adjusted return on assets (ROA/SDROA) for bank $\mathrm{i}$ and year t. $\mathrm{Yi}_{(\mathrm{t}-1)}$ is the lagged measurement of the dependent variable. FOCUS $_{\text {it }}$ is the means of measuring income diversification as defined in the preceding part. $\mathrm{NII}_{i t}$ is the percentage portion of non-interest income to total operating income. CONTROL $\mathrm{C}_{\text {it }}$ represents a vector of control variables, including size, credit risk, capital, asset composition, and asset growth. Year $_{t}$ is the year dummies in the model for the consideration of any possible impact of the business cycle.
This empirical model is then used for the three groups of banks based on ownership status to investigate whether any differences exist in the impact of income diversification across ownership status and for the two groups of banks based on financial soundness, to investigate the differences in the benefits across asset quality groups.

\section{REGRESSION RESULTS}

Here, we present the empirical results of the regression that test for any relationship between our independent and dependent variables. Then, we further investigate whether this relationship is found to be different across ownership status and asset quality groups. 


\subsection{Income Diversification and Bank Profitability}

Table II. Income Diversification and Bank Profitability of Banks in Indonesia (2007-2016)

\begin{tabular}{|c|c|c|c|c|}
\hline \multirow[t]{2}{*}{ VARIABLES } & \multirow{2}{*}{$\begin{array}{l}\mathrm{RE} \\
\mathrm{ROA}\end{array}$} & \multirow{2}{*}{$\begin{array}{l}\text { RE } \\
\text { ROASDROA }\end{array}$} & \multicolumn{2}{|l|}{ GMM } \\
\hline & & & ROA & ROASDROA \\
\hline Lagged dep. (t-1) & & & $\begin{array}{l}0.232^{* * * *} \\
(0.05400)\end{array}$ & $\begin{array}{l}0.106 * \\
(0.05850)\end{array}$ \\
\hline FOCUS & $\begin{array}{l}-0.00798^{*} \\
(0.00461)\end{array}$ & $\begin{array}{l}13.70^{*} \\
(7.05700)\end{array}$ & $\begin{array}{l}-0.00929 * \\
(0.00543)\end{array}$ & $\begin{array}{l}-61.93^{* *} \\
(25.47000)\end{array}$ \\
\hline NII & $\begin{array}{l}0.0034 \\
(0.00368)\end{array}$ & $\begin{array}{l}6.303 \\
(5.74600)\end{array}$ & $\begin{array}{l}0.0105^{* *} \\
(0.00443)\end{array}$ & $\begin{array}{l}31.46 \\
(19.42000)\end{array}$ \\
\hline $\log \mathrm{TA}$ & $\begin{array}{l}0.00348^{* * *} \\
(0.00112)\end{array}$ & $\begin{array}{l}4.611^{* * * * *} \\
(1.02300)\end{array}$ & $\begin{array}{l}0.00191 \\
(0.00290)\end{array}$ & $\begin{array}{l}-10.94 \\
(13.15000)\end{array}$ \\
\hline LLPRatio & $\begin{array}{l}-0.185^{* * *} * \\
(0.03450)\end{array}$ & $\begin{array}{l}-90.19 \\
(57.40000)\end{array}$ & $\begin{array}{l}-0.389^{* * * * *} \\
(0.04640)\end{array}$ & $\begin{array}{l}245.8 \\
(171.80000)\end{array}$ \\
\hline EquityRatio & $\begin{array}{l}0.0175^{\text {***** }} \\
(0.00308)\end{array}$ & $\begin{array}{l}5.35 \\
(4.69300)\end{array}$ & $\begin{array}{l}0.0126 \text { **** } \\
(0.00402)\end{array}$ & $\begin{array}{l}-27.34 \\
(21.14000)\end{array}$ \\
\hline LoanRatio & $\begin{array}{l}0.0119 \text { **** } \\
(0.00285)\end{array}$ & $\begin{array}{l}10.95^{* * * *} \\
(4.19200)\end{array}$ & $\begin{array}{l}0.00584 \\
(0.00409)\end{array}$ & $\begin{array}{l}7.966 \\
(13.16000)\end{array}$ \\
\hline AssetGrowth & $\begin{array}{l}-0.00410^{\text {***** }} \\
(0.00084)\end{array}$ & $\begin{array}{l}-1.451 \\
(1.44700)\end{array}$ & $\begin{array}{l}-0.00528 \text { **** } \\
(0.00119)\end{array}$ & $\begin{array}{l}-3.908 \\
(4.71300)\end{array}$ \\
\hline Constant & $\begin{array}{l}-0.0171^{*} \\
(0.01020)\end{array}$ & $\begin{array}{l}-42.77 * * * * \\
(11.84000)\end{array}$ & & \\
\hline Observations & 1062 & 1062 & 840 & 840 \\
\hline Number of Banks & 109 & 109 & 109 & 109 \\
\hline R-squared & 0.122 & 0.068 & & \\
\hline Year FE & Yes & Yes & Yes & Yes \\
\hline
\end{tabular}

Table 2 reports the results from our empirical model. The first and second columns report the regression results using static panel data estimators, and the third and fourth columns report the regression results using dynamic panel data estimators. For dynamic panel data estimators, we use a one-step difference generalized method of moments (Difference GMM) estimator. Adjusting for Windmeijer (2005), finite-sample correction is done to calculate the standard errors of the variables.

The benefits of implementing the GMM estimator are: (1) past values tend to determine the profitability values in the following years, GMM enables us to exploit the dynamic nature of the data by including lagged values of dependent variables; and (2) the possibility exists that the independent variables might not be exogenous or, in other words, the endogeneity issue might be present in the model. The Sargan test is applied to check whether the instruments used in the model are valid. The Arellano-Bond (AR) test is also used to check for any second-order correlation issue. Our diagnostic test is satisfactory for ROA as a dependent variable but unsatisfactory for risk-adjusted ROA as a dependent variable.

In general, a potential positive benefit exists to profitability and risk-adjusted profitability levels by shifting toward non-traditional bank activities from traditional bank activities, although statistical significance is not present. This result is observed in the coefficient value of FOCUS and NII. Less-diversified banks have a negative impact on profitability rate by at least $-0.79 \%$ but with a higher and positive impact on risk-adjusted profits by 13.70 . Using the FOCUS variable, our finding supports Hypothesis 1. More diversified banks do not experience a negative impact on the profitability rate because of the various revenue sources. This result is also supported by our findings using the GMM regression method. However, welldiversified banks do not obtain a positive impact of income diversification on risk-adjusted profits.

Another finding based on NII- the effect of having more non-interest income in the bank's revenue composition - is positive but not associated with higher profitability given the insignificant result of the variable. Significance is found when we use the GMM regression method with a coefficient of $1.05 \%$ to show that more diversified banks are increasing profits by raising the share of non-interest income in their income portfolios. Therefore, our finding is not in line with several previous studies (e.g., Baele et al., 2007; Meslier et al., 2014; Ahamed, 2017) but is in line and supportive of past studies that also found NII to not have a significant impact on bank profitability (e.g., Stiroh, 2002; Stiroh and Rumble, 2016).

Banks with more assets also experience a stronger impact on profitability rate and risk-adjusted profits because they have the capability to invest in many types of assets with generally higher rates of return. Another important finding is that banks with a higher loan to total assets ratio have higher profitability and riskadjusted profits, which shows that conventional banks with a higher composition of interest-bearing assets are gaining higher profitability and risk-adjusted profits than those with a more diversified portfolio of assets. Moreover, by using the GMM method, we know that the preceding year's ROA has a significant positive impact on the present year's ROA. The same case is also found in risk-adjusted profits.

\subsection{Ownership Status, Income Diversification, and Bank Profitability}

Tables 3, 4, and 5 show whether any difference exists in the level of the relationship between income diversification and profitability across bank groups based on ownership status.

In this case, we run our empirical model for each ownership group separately by applying the model to static panel data estimators. The results indicate that a positive relationship exists between less-diversified banks and bank profitability for public banks. The opposite relationship is found for the other two bank groups. However, significance is only found for foreign banks, which is mainly the result of public banks in Indonesia operating more as conventional banks, that is, as financial intermediaries between creditors and debtors. Therefore, their profitability rate increases as 
their interest income increases. Meanwhile, the same is not applicable to private and foreign banks because they are operating mainly to capture non-interest income by generating management fees and commissions because the market for intermediaries is already dominated by public banks.

Table III. Income Diversification and Bank Profitability: Differences in Public Banks (2007-2016)

\begin{tabular}{|c|c|c|}
\hline \multirow[t]{2}{*}{ VARIABLES } & \multicolumn{2}{|c|}{ Public Banks } \\
\hline & ROA & ROASDROA \\
\hline \multirow[t]{2}{*}{ FOCUS } & $0.149 * *$ & -223.5 \\
\hline & $(0.064)$ & $(225.600)$ \\
\hline \multirow[t]{2}{*}{ NII } & $0.268^{* *}$ & -382 \\
\hline & $(0.107)$ & $(355.700)$ \\
\hline \multirow[t]{2}{*}{ LogTA } & 0.00785 & $4.637 *$ \\
\hline & $(0.012)$ & $(2.430)$ \\
\hline \multirow[t]{2}{*}{ LLPRatio } & $-0.273 * * *$ & -107.9 \\
\hline & $(0.046)$ & $(167.200)$ \\
\hline \multirow[t]{2}{*}{ EquityRatio } & $0.137 * * *$ & 61.03 \\
\hline & $(0.028)$ & $(43.860)$ \\
\hline \multirow[t]{2}{*}{ LoanRatio } & 0.00262 & $24.28 * *$ \\
\hline & $(0.007)$ & $(11.480)$ \\
\hline \multirow[t]{2}{*}{ AssetGrowth } & $-0.00433^{*}$ & -0.102 \\
\hline & $(0.002)$ & $(5.305)$ \\
\hline \multirow[t]{2}{*}{ Constant } & $-0.205^{*}$ & 179.2 \\
\hline & $(0.119)$ & $(220.900)$ \\
\hline Observations & 304 & 304 \\
\hline Number of BankID & 31 & 31 \\
\hline Estimation technique & FE & $\mathrm{RE}$ \\
\hline R-squared & 0.400 & 0.073 \\
\hline Year FE & Yes & Yes \\
\hline \multicolumn{3}{|c|}{$* * *$ implies significance at $1 \%$, respectively } \\
\hline \multicolumn{3}{|c|}{$* *$ implies significance at $5 \%$, respectively } \\
\hline \multicolumn{3}{|c|}{ * implies significance at $10 \%$, respectively } \\
\hline
\end{tabular}

Table IV. Income Diversification and Bank Profitability: Differences in Private Banks (2007-2016)

\begin{tabular}{lll}
\hline VARIABLES & \multicolumn{2}{l}{ Private Banks } \\
\cline { 2 - 3 } FOA & ROASDROA \\
\hline \multirow{2}{*}{ FOCUS } & -0.0422 & -14.55 \\
NII & $(0.063)$ & $(95.700)$ \\
& -0.0637 & -32.21 \\
LogTA & $(0.100)$ & $(150.200)$ \\
& $0.00906 * *$ & $5.192 * * *$ \\
LLPRatio & $(0.004)$ & $(1.617)$ \\
& -0.0288 & -127.1 \\
EquityRatio & $(0.236)$ & $(80.700)$ \\
& $0.0303 * * *$ & 8.723 \\
LoanRatio & $(0.008)$ & $(7.750)$ \\
& $0.0189 * * *$ & 8.422 \\
AssetGrowth & $(0.007)$ & $(7.200)$ \\
& $-0.00336 *$ & -1.573 \\
Constant & $(0.002)$ & $(1.806)$ \\
& -0.0349 & -18.32 \\
& $(0.065)$ & $(96.770)$ \\
Observations & & \\
Number of BankID & 506 & 506 \\
Estimation technique & FE & 52 \\
R-squared & 0.152 & RE \\
Year FE & Yes & Yes \\
\hline *** implies significance at 1\%, respectively \\
** implies significance at $5 \%$, respectively \\
$*$ implies significance at $10 \%$, respectively \\
\hline
\end{tabular}

Table V. Income Diversification and Bank Profitability: Differences in Foreign Banks (2007-2016)

\begin{tabular}{|c|c|c|}
\hline \multirow[t]{2}{*}{ VARIABLES } & \multicolumn{2}{|c|}{ Foreign Banks } \\
\hline & ROA & ROASDROA \\
\hline FOCUS & $\begin{array}{l}-0.0158^{* *} \\
(0.007)\end{array}$ & $\begin{array}{l}4.166 \\
(5.289)\end{array}$ \\
\hline NII & $\begin{array}{l}0.00633 \\
(0.004)\end{array}$ & $\begin{array}{l}9.886^{* * * *} \\
(3.637)\end{array}$ \\
\hline $\operatorname{LogTA}$ & $\begin{array}{l}0.000609 \\
(0.003)\end{array}$ & $\begin{array}{l}1.873 \\
(1.576)\end{array}$ \\
\hline LLPRatio & $\begin{array}{l}-0.238 * * * \\
(0.072)\end{array}$ & $\begin{array}{l}3.803 \\
(64.300)\end{array}$ \\
\hline EquityRatio & $\begin{array}{l}0.0112^{* *} \\
(0.005)\end{array}$ & $\begin{array}{l}1.357 \\
(4.078)\end{array}$ \\
\hline LoanRatio & $\begin{array}{l}0.00303 \\
(0.006)\end{array}$ & $\begin{array}{l}12.65 * * * \\
(4.049)\end{array}$ \\
\hline AssetGrowth & $\begin{array}{l}-0.00730 * * * \\
(0.002)\end{array}$ & $\begin{array}{l}-1.276 \\
(1.864)\end{array}$ \\
\hline Constant & $\begin{array}{l}0.0144 \\
(0.022)\end{array}$ & $\begin{array}{l}-23.95^{*} \\
(13.300)\end{array}$ \\
\hline Observations & 252 & 252 \\
\hline Number of BankID & 26 & 26 \\
\hline Estimation technique & $\mathrm{RE}$ & $\mathrm{RE}$ \\
\hline R-squared & 0.270 & 0.121 \\
\hline Year FE & Yes & Yes \\
\hline $\begin{array}{l}\text { *** implies significar } \\
\text { ** implies significanc } \\
\text { * implies significance }\end{array}$ & $\begin{array}{l}\text { at } 1 \% \text {, resp } \\
\text { at } 5 \%, \text { respec } \\
\text { at } 10 \%, \text { respe }\end{array}$ & $\begin{array}{l}\text { tively } \\
\text { vely } \\
\text { ively }\end{array}$ \\
\hline
\end{tabular}

Based on NII, we can conclude that a positive significant relationship is only found for public banks with more diversified income sources, which have $26.8 \%$ higher profitability than those with lessdiversified income portfolios. A positive but not significant relationship is also found for foreign banks.

The positive impact of FOCUS and NII on bank profitability for the public bank group shows that the group may enjoy the benefit of income diversification in the future because of the government's efforts toward the privatization of public banks. Therefore, our finding supports Hypothesis 2 because the impact of income diversification is different for each group of banks based on ownership status.

\subsection{Asset Quality, Non-Interest Income, and Bank Profitability}

Table 6 presents the regression results of noninterest income and profitability on two different groups based on asset quality. The regression results are based on our empirical model. We use the LLP ratio to determine whether a bank is classified as having low or HAQ. In general, the result shows that lower asset quality banks are able to generate higher profits and risk-adjusted profits by diversifying their income portfolio. Although the effect is still mainly from the lagged dependent variable, NII and FOCUS have a 
significant positive impact on risk-adjusted ROA for the LAQ group.

Significance also exists for the HAQ group, meaning that banks with higher asset value also generate higher profits by diversifying their income portfolios by increasing the non-interest income proportion. Under the GMM method, we also find similar results with a significant positive impact of non-interest income on profitability rate.

Table VI. Asset Quality, Income Diversification, and Profitability of Banks in Indonesia (2007-2016)

\begin{tabular}{|c|c|c|c|c|}
\hline \multirow[t]{2}{*}{ VARIABLES } & \multirow{2}{*}{$\begin{array}{l}\mathrm{RE} \\
\mathrm{ROA}\end{array}$} & \multirow{2}{*}{$\begin{array}{l}\text { RE } \\
\text { ROASDROA }\end{array}$} & \multicolumn{2}{|l|}{ GMM } \\
\hline & & & ROA & ROASDROA \\
\hline Lagged dep. (t-1) & & & $\begin{array}{l}0.222 * * * \\
(0.055)\end{array}$ & $\begin{array}{l}0.131^{\text {*** }} \\
(0.058)\end{array}$ \\
\hline NII x LAQ Banks & $\begin{array}{l}0.00461 \\
(0.004)\end{array}$ & $\begin{array}{l}2.031 \\
(5.461)\end{array}$ & $\begin{array}{l}0.0065 \\
(0.006)\end{array}$ & $\begin{array}{l}19.21^{*} \\
(11.640)\end{array}$ \\
\hline NII x HAQ Banks & $\begin{array}{l}0.00826^{* *} \\
(0.004)\end{array}$ & $\begin{array}{l}-5.147 \\
(4.955)\end{array}$ & $\begin{array}{l}0.00927 * \\
(0.005)\end{array}$ & $\begin{array}{l}7.361 \\
(10.180)\end{array}$ \\
\hline HAQ Banks & $\begin{array}{l}0.0012 \\
(0.001)\end{array}$ & $\begin{array}{l}0.0521 \\
(1.232)\end{array}$ & $\begin{array}{l}0.000885 \\
(0.001)\end{array}$ & $\begin{array}{l}-0.346 \\
(1.865)\end{array}$ \\
\hline $\log T A$ & $\begin{array}{l}0.00383^{* * * *} \\
(0.001)\end{array}$ & $\begin{array}{l}3.493 * * * \\
(0.972)\end{array}$ & $\begin{array}{l}0.0024 \\
(0.003)\end{array}$ & $\begin{array}{l}5.189 \\
(6.507)\end{array}$ \\
\hline EquityRatio & $\begin{array}{l}0.0165^{* * *} \\
(0.003)\end{array}$ & $\begin{array}{l}3.058 \\
(4.675)\end{array}$ & $\begin{array}{l}0.0109^{* * * *} \\
(0.004)\end{array}$ & $\begin{array}{l}-2.438 \\
(8.823)\end{array}$ \\
\hline LoanRatio & $\begin{array}{l}0.0106 * * * \\
(0.003)\end{array}$ & $\begin{array}{l}9.119 * * \\
(4.204)\end{array}$ & $\begin{array}{l}0.00514 \\
(0.004)\end{array}$ & $\begin{array}{l}4.083 \\
(8.918)\end{array}$ \\
\hline AssetGrowth & $\begin{array}{l}-0.00383 \text { *** } \\
(0.001)\end{array}$ & $\begin{array}{l}-1.29 \\
(1.451)\end{array}$ & $\begin{array}{l}-0.00382^{\text {**** }} \\
(0.001)\end{array}$ & $\begin{array}{l}-2.129 \\
(2.590)\end{array}$ \\
\hline Constant & $\begin{array}{l}-0.0274^{* * * *} \\
(0.008)\end{array}$ & $\begin{array}{l}-21.50^{* * *} \\
(8.009)\end{array}$ & & \\
\hline Observations & 1,062 & 1,062 & 840 & 840 \\
\hline Number of BankID & 109 & 109 & 109 & 109 \\
\hline R-squared & 0.110 & 0.058 & & \\
\hline Year FE & Yes & Yes & Yes & Yes \\
\hline $\mathrm{AR}(2)$ & & & 0.427 & 0.011 \\
\hline Sargan test & & & 93.680 & 21.920 \\
\hline Sargan test p-value & & & 0.000 & 0.404 \\
\hline
\end{tabular}

Our finding is in line and supports the previous study by Ahamed (2017). Banks with LAQ tend to search for more sources of income other than traditional lending activities to gain benefits that may overshadow the loss of bad debt. In conclusion, our finding is supportive of Hypothesis 3 because greater benefits exist for lower asset quality groups than for higher asset quality groups. During the last few years, the quality of assets of banks in Indonesia has been deteriorating; thus, banks' efforts toward income diversification is increasing, such as starting to provide fee-based, commission-based, and trading-based activities to obtain higher revenue.

\section{CONCLUSION}

The empirical evidence presented in developed countries on the possible link of income diversification with bank profitability is unclear because of the mixed results for different countries. Some studies found that diversifying income sources for banks does not have a positive relationship with bank profitability in developed markets. Meanwhile, other studies found the opposite: that well-diversified banks generate higher profitability than less-diversified banks.

In this research, the probable impact of the increasing value of non-interest sources of income on Indonesian bank profitability for the period 2007-2016 has been investigated. We further explored the relationship by separating the banks in our sample data into three groups based on ownership status and into two groups based on asset quality level. We also run the model using a one-step difference GMM together with static panel data estimators and fixed/random effects estimators to count for the dynamics in our dataset and to avoid endogeneity issues that are often found in research models.

Overall, we find a positive impact of income diversification, measured by NII, on bank profitability, measured by ROA and risk-adjusted ROA. An important point to note is that, although a positive relationship exists between the two variables, statistical significance was not found using static or dynamic panel data estimators. Nevertheless, the result is consistent with existing studies that support the notion that income diversification does not have a positive relationship with bank profitability in developed countries (e.g., Stiroh, 2002; Stiroh and Rumble, 2006) but contrasts with findings from developing market economies (e.g., Sanya and Wolfe, 2011; Nguyen et al., 2012; Meslier et al., 2014). This contrast may result from the financial sector in Indonesia being highly affected and following the U.S. financial sector. In addition, we find a significant negative impact of income diversification, measured by FOCUS, on bank profits and risk-adjusted profits. This impact shows that more focused banks, i.e., less-diversified banks, generate lower and risk-adjusted profits.

We also found that the impact of income diversification on profits and risk-adjusted profits differs across different ownership status. Public banks seem to enjoy higher profitability by focusing their income on traditional activities that generate interest income. Meanwhile, foreign banks enjoy higher and risk-adjusted profits by diversifying their income sources. These higher profits are the result of the different markets that each group of banks targets in the market, with public banks acting as financial intermediaries between creditors and debtors and private banks and foreign banks providing services that generate higher management fees and commissions.

Lastly, we found that income diversification resulted in greater benefits to lower asset quality banks than those in the higher asset quality group. This is mainly because banks with LAQ are searching for income sources other than interest income to gain benefits that are higher than the risk of the bad debt incurred through traditional lending activities. 


\section{REFERENCES}

[1] Acharya, V.V., Hasan, I., Saunders, A., 2006. Should banks be diversified? Evidence from individual bank loan portfolios. J. Bus. 79, 13551412.

[2] Ahamed, M. 2017. Asset quality, non-interest income, and bank profitability: Evidence from Indian banks. Econ. Model. 63, 1-14.

[3] Baele, L., De Jonghe, O., Vander Vennet, R., 2007. Does the stock market value bank diversification? J. Bank. Finance 31, 1999-2023.

[4] Banerjee, S., Velamuri, M., 2015. The conundrum of profitability versus soundness for banks by ownership type: evidence from Indian banking sector. Rev. Financial Econ. 26, 12-24.

[5] Banking Sector Indonesia: NPL Ratio Improved in June 2017. (2017). Retrieved from https://www.indonesiainvestments.com/news/todays-headlines/bankingsector-indonesia-npl-ratio-improved-in-june2017/item8004?

[6] Beck, T., Demirguc-Kunt, A., Merrouche, O., 2013. Islamic vs. conventional banking: business model, efficiency and stability. J. Bank. Finance $37,433-147$.

[7] Berger, A., Klapper, L., Turk-Ariss, R., 2009. Bank competition and financial stability. J. Financial Serv. Res. 35, 99-118.

[8] Chiorazzo, V., Millani, C., Salvini, F., 2008. Income diversification and bank performance: evidence from Italian banks. J. Financial Serv. Res. 33, 181-203.

[9] Cicilia, S., 2017. Pendapatan non-bunga bantu profitabilitas bank. Kontan. Retrieved from http://keuangan.kontan.co.id/news/pendapatannon-bunga-bantu-profitibilitas-bank

[10] Das, A., Ghosh, S., 2006. Financial deregulation and efficiency: An empirical analysis of Indian banks during the Post Reform period. Review of Financial Economics, 15(3):193-221.

[11] DeYoung, R., Roland, K.P., 2001. Product mix and earnings volatility at commercial banks: evidence from a degree of total leverage model. J. Financial Intermediat. 10, 54-84.

[12] Dupla, K.S., 2016. Perbankan maksimalkan pendapatan non-bunga. Kontan. Retrieved from http://keuangan.kontan.co.id/news/perbankanmaksimalkan-pendapatan-non-bunga
[13] Elsas, R., Hackethal, A., Holzhauser, M., (2010). The anatomy of bank diversification. J. Bank. Finance 34, 1274-1287.

[14] Garza-Garcia, J.G., (2012). Does market power influence bank profits in Mexico? A study on market power and efficiency. Appl. Financial Econ. 22, 21-32.

[15] Goddard, J. McKillop, D., Wilson, J.O. (2008). The diversification and financial performance of US credit unions. J. Bank. Finance. 32, 1836-1849.

[16] Indonesia Non Performing Loans Ratio. 2017. Retrieved from https://www.ceicdata.com/en/indicator/indonesia/n on-performing-loans-ratio

[17] Iskandar-Datta, M., McLaughlin, R., 2007. Global diversification: new evidence from corporate operating performance. Corp. Ownersh. Control 4, 228-250.

[18] Laeven, L. , Majnoni, G., 2003. Loan loss provisioning and economic slowdowns: too much, too late? J. Fin. Intermediation, 12, 178-197.

[19] Mergaerts, F., Vander Vennet, R., 2015. Business models and bank performance: A long-term perspective. J. Fin. Stability, 22, 57-75.

[20] Meslier, C., Tacneng, R., Tarazi, A., 2014. Is bank income diversification beneficial? Evidence from an emerging economy. J. Int. Financial Mark. Inst. Money 31, 97-126.

[21] Mirza, N., Rahat, B., Reddy, K., (2015). Business dynamics, efficiency, asset quality and stability: the case of financial intermediaries in Pakistan. Econ. Model. 46, 358-363.

[22] Nguyen, M., Skully, M., Perera, S., 2012. Market power, revenue diversification and bank stability: evidence from selected South Asian countries. J. Int. Financial Mark. Inst. Money 22, 897-912.

[23] Pennathur, A.K., Subrahmanyam, V., Vishwasrao, S., 2012. Income diversification and risk: does ownership matter? An empirical examination of Indian banks. J. Bank. Finance 36, 2203-2215.

[24] Sanya, S., Wolfe, S., 2011. Can banks in emerging economies benefit from revenue diversification? $\mathrm{J}$ Financial Serv. Res. 40, 79-101.

[25] Sejarah Bank Indonesia: Perbankan. 1997. Retrieved from http://www.bi.go.id/id/tentangbi/museum/sejarahbi/bi/Documents/25d8c7b0fbbe4d27bf24497e5a0f3 dfaSejarahPerbankanPeriode19831997.pdf 
[26] Stiroh, K.J., 2002. Diversification in banking: is noninterest income the answer? J. Money Credit Bank., 853-882.

[27] Stiroh, K.J., Rumble, A., 2006. The dark side of diversification: the case of US financial holding companies. J. Bank. Finance 30, 2131-2161.
[28] Tabak, B., Tecles, P. Langsch, 2010. Determinants of bank efficiency: The case of Brazil. European Journal of Operational Research, 207, 1587-1598.

[29] Windmeijer, F., 2005. A finite sample correction for the variance of linear efficient two-step GMM estimators. J. Econometrics, 126, 25-51. 